\title{
EDITÖRE MEKTUP: HAC YOLUNDA BIR KARINCA, PROF. DR. MEHMET GENÇ
}

Letter to the Editor: An Ant on the Way of Pilgrimage, Prof. Dr. Mehmet Genç

\section{Cumali BOZPINAR*}

\section{Sayın Editör,}

Anadolu coğrafyasına yönelik sosyal bilim çalışmalarında Osmanlı Devleti'nin son dönemlerinden beri kapitalist insan tipinin ortaya çıkamamasının sebepleri üzerine tartışmalar "the grand problematic" (büyük sorunsal) olarak nitelenebilir. Meseleye piyasa kurumunun varlığı noktasından bakıldığında, zihniyet araştırmalarının soruna yönelik açıklamalarının bir adım önde olduğu kabul edilebilir. Bu öncülüğü bir bayrak yarışı koşucusu gibi kendine misyon edinmiş, kendi tabiriyle "Hac yolunda bir karınca" Prof. Dr. Mehmet Genç, 18 Mart 2021 günü sonsuzluğa koşmuştur. Bu vesileyle kaleme aldığım bu mektupta, kendime rehber edindiğim merhumun "karınca çalışkanlığı”yla ilgili olarak önemli gördüğüm birkaç hususu kısa ve özlü bir şekilde açıklamayı bir vefa borcu olarak gördüğümü belirtmek isterim.

Merhumun hayat hikâyesiyle başlamak uygun olacaktır. Mehmet Genç, 1934'te Artvin'in Arhavi ilçesinde dünyaya gelmiş olup, istanbul'da Haydarpaşa Lisesini 1953'te, Ankara Üniversitesi Siyasal Bilgiler Fakültesi Maliye ve iktisat Bölümünü ise 1958'de bitirmiştir. Mezuniyet sonrasında 1959'de maiyet memurluğu görevi olarak Şereflikoçhisar kaymakam vekilliği yapmıştır. 1960 yılında girdiği i̇stanbul Üniversitesi îktisat Fakültesi Türk iktisat Tarihi Enstitüsü iktisat Tarihi Kürsüsünde Ord. Prof. Dr. Ömer Lütfi Barkan'ın yanında asistan olarak çalışmıştır. Doktora tezini zamanında bitiremediği için asistanlığına son verilmiş, bunun üzerine hocası tarafından aynı enstitüye uzman olarak alınmıştır. 1983 yılında Marmara Üniversitesi Fen Edebiyat Fakültesi Tarih Bölümünde öğretim görevlisi olarak çalışmaya başlamıştır. 1999 yılında emekli olduktan sonra sırasıyla İstanbul Teknik Üniversitesi insan ve Toplum Bilimleri Bölümünde, İstanbul Bilgi Üniversitesi Tarih Bölümünde, İstanbul Üniversitesi Edebiyat Fakültesi Sosyoloji Bölümünde ve İstanbul Şehir Üniversitesi İnsani Bilimler Fakültesi Tarih Bölümünde dersler

\footnotetext{
* Dr., Çevre ve Şehircilik Bakanlığı, Milli Emlak Genel Müdürlüğü, Ankara/Türkiye. E-posta: cumalispontik@gmail.com. ORCID ID: 0000-0003-0948-1659.
} 
vermiştir. 2015 yılında sosyal bilimler ve tarih alanında Cumhurbaşkanlığı Kültür ve Sanat Büyük Ödülüne layık görülmüştür (URL-1; URL-2).

Prof. Dr. Mehmet Genç, Osmanlı iktisat tarihi üzerine Osmanlı arşiv belgelerine dayalı olarak yaklaşık 40 yıllık sabırlı çalışmasının sonucunda Osmanlı insanının iktisadi dünya görüşünün temel ilkelerini ortaya koymayı başarmıştır. Bu ilkeler bir bütün halinde, kapitalist nitelikte bir rasyonalitesi olmayan Osmanlı insanının temel olarak geleneksel değerler çerçevesinde şekillenmiş bir rasyonalitesi olduğunu göstermektedir. Bu zihniyetin önemini şöyle ifade etmiştir:

Osmanlı dünyası hakkında, milliyetçiliğin etkisi altında yumuşatılmış şekli içinde de olsa olumsuzluğunu koruyan (...) yaygın tasavvur çağdaş bir mitostan ibaretti. Mitosun temelinde yatan, Osmanlı'dan bize intikal eden ekonominin zengin olmaması idi. Eğer zengin ve müreffeh bir ekonomi miras bırakmış olsalardı, onların zevk ü safa içindeki saray entrikaları, keyfi yönetimleri, sadece kaba kuvvete dayanmaları ve daha birçok günahları doğru olsun olmasın mazur görülebilir, hatta sempatik bile karşılanabilirdi. (...) Saf bir şekilde "bu camileri yapacaklarına, bize birkaç fabrika bıraksalardı çok daha iyi olurdu" diyen pek çok muteber zevata rastladığımı hatırlıyorum. Bugün de aynı temenniyi ifade edenler var mıdır, bilmiyorum. Bu safdillikle temennilerin, miras kalan koskoca bir vatanla, bu mitosa rağmen, hayat dolu bir millî varlığı tarihin cehennemi fırınından salimen çıkararak 20. yüzyıla teslim edenin de neticede Osmanlı sistemi olduğunu hiç hatırlamamasındaki körlük çok açıktı (Genç, 2012: 17).

Emektar "Hac yolunda bir karınca"nın burada ifade ettiği "hiç hatırlamamak körlüğü”, esasında unutmuş olmaktır. Dolayısıyla bugünkü toplumu anlayabilmek için geçmişinin öğrenilmesinin önemi kendiliğinden ortaya çıkmaktadır. Merhum Prof. Dr. Mehmet Genç'in muhtelif makaleleri Ötüken Neşriyat yayınlarından Osmanlı imparatorluğu'nda Devlet ve Ekonomi başlıklı kitapta bir araya toplanmış olup bu kitap Osmanlı iktisat tarihi alanında bir rehber niteliği taşımaktadır. Geçmişini unutanın körlüğünü yaşamamak için bu rehberin okunmasını tavsiye ediyorum. Bu mektup Türk iktisat tarihçiliğinin çalışkan isimlerinden Mehmet Genç'in beni etkileyen fikirsel yönünün kısa bir ifadesidir. O, son nefesine kadar çalışkan bir insan olarak yaşamıştır. Merhum hocamızın aziz hatırası önünde saygıyla eğiliyorum. 


\section{Kaynakça}

Genç, Mehmet (2012). Osmanlı Imparatorluğunda Devlet ve Ekonomi. İstanbul: Ötüken Neşriyat.

URL-1: “CV”. https://sehir.academia.edu/MGen\%C3\%A7/CurriculumVitae. (Erişim: 15.04.2021).

URL-2: "Tarihçi Mehmet Genç Hayatını Kaybetti”. www.birgun.net/haber/ tarihci-mehmet-genc-hayatini-kaybetti-338068. (Erişim: 15.04.2021). 